\title{
Mopping Up or Turning Off the Tap? Environmental Injustice and the Ethics of Plastic Pollution
}

\author{
Katharine A. Owens ${ }^{1 *}$ and Katie Conlon ${ }^{2}$ \\ ${ }^{1}$ Department of Politics, Economics, and International Studies, University of Hartford, West Hartford, CT, United States, \\ ${ }^{2}$ Nohad A. Toulan School of Urban Studies and Planning, College of Urban and Public Affairs, Portland State University, \\ Portland, OR, United States
}

Keywords: plastic pollution, industry, framing, policy, green washing, marine debris, environmental justice

\section{THE PROBLEM WITH PLASTICS}

Decades of scientific research confirm that plastic pollution poses a threat to many species, to water resources, and to economies around the world (Laist, 1997; Barnes et al., 2009; Gregory, 2009;

\section{OPEN ACCESS}

Edited by:

Angel Borja,

Technological Center Expert in Marine and Food Innovation (AZTI), Spain

Reviewed by:

Williams Allan

University of Wales Trinity Saint David,

United Kingdom

Sabine Pahl

University of Vienna, Austria

${ }^{*}$ Correspondence:

Katharine A. Owens

kowens@hartford.edu

Specialty section:

This article was submitted to

Marine Pollution,

a section of the journal

Frontiers in Marine Science

Received: 24 May 2021 Accepted: 09 August 2021

Published: 30 August 2021

Citation:

Owens KA and Conlon K (2021)

Mopping Up or Turning Off the Tap?

Environmental Injustice and the Ethics of Plastic Pollution.

Front. Mar. Sci. 8:713385. doi: 10.3389/fmars.2021.713385
Teuten et al., 2009; Chen, 2015; Newman et al., 2015; Rochman, 2015). Experts demonstrate that oceanic plastic pollution is increasing at astounding rates (Eriksen et al., 2014; Geyer et al., 2017). Research indicates harmful levels of toxicity in everyday plastic items (SCP/RAC, 2020). Scientists find this issue so important that they have recommended plastics be classified as a pollutant on par with hazardous waste (Mouat et al., 2010; Rochman et al., 2013) or that single use plastics should be banned (Telesetsky, 2019). For many years, experts have noted that increasing plastic manufacturing and use will worsen the condition in the marine environment (Carpenter and Smith, 1972; Azzarello and Van Vleet, 1987; Gregory, 2009) and yet the global plastic industry continues to increase production, cumulatively producing 368 million tons in 2019 (PlasticsEurope, 2020). If current growth trajectories continue, by 2050 plastic could account for $20 \%$ of global oil production (Giacovelli, 2018) and the world could have four times the amount of plastic waste that we generate today (Geyer et al., 2017). Plastic debris contributes to a comprehensive global environmental problem that -if current trends continue- will worsen significantly (Borrelle et al., 2020; Silva et al., 2020). The COVID-19 crisis only exacerbates the problem, as it has led to an increase in the use of single use plastics in the form of personal protection equipment, which researchers have already begun to see in the environment at high levels (Ammendolia et al., 2021; Mejjad et al., 2021).

The majority of the plastic pollution problem falls disproportionately on the global south, especially in south and southeast Asia (Jambeck et al., 2015; Lebreton et al., 2017), creating an issue of slow violence (Homer-Dixon, 2000) and environmental injustice. While plastic pollution is universal, some consequences such as clogged drainage systems, increases in vector-borne diseases, and reduction in tourism are particularly felt in poorer communities, where solid waste management systems are not in place (Barnett, 1997; Coe and Rogers, 1997; Liffmann and Boogaerts, 1997; Jambeck et al., 2015; The Ocean Conservancy, 2015; Lebreton et al., 2017; Giacovelli, 2018; Godfrey, 2019). Plastics may be exported from the developed world to the developing world for legal or illegal disposal (Blettler and Wantzen, 2019; McCormick et al., 2019). In poorer communities, plastics may be burned as fuel (heat or cooking) or in disposal (Giacovelli, 2018). Poorer communities may also be selected as sites for plastic manufacturing (Ramirez, 2021).

Responsibility for managing plastic waste often falls on the people and places least responsible for producing said waste (Conlon, 2020). 


\section{"MISMANAGED WASTE" IN THE GLOBAL SOUTH}

Critically, the way we frame the story of plastic pollution has consequences for the proposed solutions. The framing of the plastic problem typically focuses on a handful of south and southeast Asian countries where the problems of waste are most visible (Lebreton et al., 2012, 2017; Jambeck et al., 2015; Schmidt et al., 2017). This is not surprising, as these countries often represent the nexus of high population, communities clustered near river and coastal areas, extreme poverty, and a lack of waste infrastructure. Such framing fails to recognize the way issues of privilege and justice influence the distribution of debris around the world. This framing ignores the complex relationships between the industries that sell plastics, the people who use them, and how waste is handled and exported globally (Heinrich Böll Foundation., 2019). Such framing does not hold manufacturers in the developed world accountable for marketing materials in the developing world that they know will be "mismanaged." It does not account for the economic factors that drive individuals to purchase goods, often wrapped in plastic, in small quantities. It also clouds the reality that people in all countries use singleuse plastics and few are immune from contributing to this global problem.

It is true that waste infrastructure is limited or non-existent in many countries and that a lack of waste infrastructure contributes to debris accumulation (Kaza et al., 2018). Yet, when researchers frame the problem of plastic pollution as "mismanaged waste" it gives the impression that if developing countries can simply "manage" their waste, then the problem will be solved. In this way, plastic pollution may be less visible but is no less pervasive in western communities with adequate solid waste management. Most developed countries serve as models of waste infrastructure, and yet still suffer from, and are a source of, marine litter (Law et al., 2020). In these more affluent communities, plastics are collected and then incinerated or buried, dispersing their chemical loads into the air and soil (Yang et al., 2015; Aryan et al., 2019; Blettler and Wantzen, 2019). In fact, a great deal of debris accumulates in freshwater and ocean and coastal systems in developed countries each year (Moore et al., 2005; Williams et al., 2011; Rosevelt et al., 2013; Lee and Sanders, 2015; Baldwin et al., 2016; Cable et al., 2017; Hardesty et al., 2017; Castro-Jiménez et al., 2019). In this way, framing the problem as mismanaged waste leads to a "solution" of more waste management. While increasing waste management may lessen the impacts of the problem, it cannot solve it.

What does "management" of plastic waste look like? Current packaging material flows indicate linear paths wherein about $14 \%$ of plastic is incinerated; $40 \%$ is landfilled; and $32 \%$ leaks out into the environment as litter or debris (World Economic Forum, 2016). Of the 14\% of plastic collected for recycling, only $2 \%$ has been recycled in a closed loop (a 1:1 ratio); $8 \%$ is down-cycled; and $4 \%$ is lost in the recycling process (World Economic Forum, 2016). After decades of recycling narratives, the dysfunction of recycling systems reveal plastic recycling was not designed to solve the plastic waste problem, but to be a distraction to continue production
(Sullivan and Gonzales, 2020). The issue of design should not be underestimated. Without conscientious design, communities will necessarily continue to grapple with voluminous waste. In other management scenarios, when plastic waste is landfilled as a part of municipal solid waste, local government and taxpayers pay for the land on which waste will be placed and the longterm health costs as this waste slowly degrades over decades and centuries releasing ethylene and methane (Royer et al., 2018), as well as poisoning soils and groundwater. When burned, municipal solid waste yields "emissions to air and chemical waste residuals" (Dijkgraaf and Vollebergh, 2003:2), which are also costs borne by the local community. Some researchers believe waste to energy incineration models have low externality costs, when they include "state-of-the-art air pollution control technology" and when "pre-sorting minimizes the potential for air toxics release" (Miranda and Hale, 1997:599). Yet, a study by Dijkgraaf and Vollebergh (2003) found "much higher gross environmental cost for a [waste to energy] plant than for a modern landfill" even when considering the constraints of available land for this purpose. According to the World Economic Forum (2016), incineration infrastructure may lock out "highervalue mechanisms" like recycling, carry a risk of "negative health effects," and yield by-products that also must be "disposed of" (26). This report names three primary externalities associated with plastics and plastic packaging: "leakage, especially in the ocean; the greenhouse gas emissions ... from production and after-use incineration; and health and environmental impacts from substances of concern" (World Economic Forum, 2016:28). As a long-term solution for the problem of plastic waste, managing the increasing waste through infrastructure is limited, and too often a case of distancing waste to areas and populations with less power to regulate it (Clapp, 2002). To illustrate how different approaches can emphasize up-stream or down-stream solutions, we share examples of two organizations seeking to address plastic pollution: the Alliance to End Plastic Waste and Common Seas.

\section{THE ALLIANCE TO END PLASTIC WASTE}

The Alliance to End Plastic Waste (AEPW) is a group of multinational and international companies "working to make the dream of a world without plastic waste a reality" [(AEPW, 2019):1]. The organization's mission is to: "develop, accelerate, and deploy solutions; engage communities; catalyze investments" (AEPW, 2020:5). Their proposed outcomes are: "demonstrated and scaled plastic waste-free cities in priority regions; enabled local ownership of waste management; demonstrated investable models, and partnerships that unlock even more capital to end plastic waste" (AEPW, 2020: 5). Initially in 2019, the AEPW membership pledged 1.5 billion dollars over 5 years in an "effort to end plastic waste in the environment" (AEPW, 2019:1). A contribution of 1.5 billion dollars represents $<2 \%$ of their annual net profits (Owens, 2019). Moreover, the 28 founding members of the AEPW are a part of plastics and related industries, including plastics packaging, petrochemicals, chemicals, fossil fuels (oil and gas), personal health/care products, and water- and waste- 
management. The Plastic Waste Makers Index (Charles et al., 2021) reveals that eight of the AEPW members fall within the top 100 plastics producers that account for $90 \%$ of plastic globally, including the top two producers ${ }^{1}$. While it is admirable that these industries recognize the problem their products cause, their stated goal to "make the dream of a world without plastic waste a reality" in some ways conflicts with their role in producing this waste.

The AEPW writes in their 2020 progress report, they will address plastic waste by:

- Developing and accelerating technologies;

- Partnering with the extended global community; and

- Catalyzing capital.

To guide their work, they propose to "think globally and act locally; to collaborate; to change behavior; to recover and extract value from waste plastic; and to shift from short-term actions to long-lasting waste management solutions that help communities and society achieve circular economies" (AEPW, 2020: 4). Finally, the report emphasizes their four strategies: "infrastructure, innovation, education and engagement, and cleanup" (AEPW, 2020: 5).

The progress report shares several case studies that on the surface sound effective. Yet, their framing of plastic waste challenges emphasizes the end user, not the producers of the plastics. Responsibility of plastics generation is deflected from the members of the AEPW and other producers. For instance, one, from "Project Stop" Jembrana in Indonesia, emphasizes "waste segregation at the household level" and recycling. The project description highlights "local responsibility" (AEPW, 2020: 10). Framing pollution as the responsibility of the end user rather than the manufacturer is not novel. This was also the case with the American "crying Indian" anti-litter campaign from the 1970s, funded by "bottled beverage and packaging industries" through the Ad Council, whose commercials "reinforce the propensity that readily exists in our society to reduce social problems to personal challenges" (Melillo, 2013). The print campaign included a charge to the public: People start pollution. People can stop it. while failing to recognize the interplay of design, manufacturing, use, and options for disposal. Campaigns that shift responsibility directly conflict with the concept that polluters should be responsible for the end of life of the products they manufacture and sell (i.e., a Producers Pay Principle or Polluters Pay Principle).

The report also details the Plug and Play accelerator project created "to foster start-ups that can impact the plastic value chain" (AEPW, 2020:11). Small teams work for 12 weeks to co-develop innovations with expert advice from Alliance members. The 10 solutions described in the report include using robots to more cheaply sort recycling; using biotech to "convert[] under-used carbon into high-value industrial

\footnotetext{
${ }^{1}$ AEPW members on the Plastic Wastemakers Index: Exxon (1st), Dow (2nd), Lyondell Basell (7th); Braskem (9th); Mitsubishi Chemical (31st); Sasol (38th); Mitsui Chemicals (37th) and Shell (51st) (Charles et al., 2021). The top 20 producers account for $50 \%$ of global plastic waste; and the top 100 account for $90 \%$ (ibid.).
}

products;" creating materials of $100 \%$ plastic waste; using crowdsourcing to enable citizens to clean the planet; envisioning "recycling the unrecyclable;" better technology to enable curbside recycling of plastic film; using AI and robotics to sort trash from recyclables in bins; "connecting recycled plastics with trusted suppliers from around the world;" creating roof "cover boards" from plastic and paper that would otherwise enter landfills; and recycling plastics into "environmentally friendly fuels" (AEPW, 2020: 13). These are overwhelmingly end-of-pipe clean-up solutions that do not address upstream production. The report shares information on two other Indonesian projects, which are briefly described as converting "plastic waste into a petrochemical feedstock" (AEPW, 2020: 15). Continuing, in collaboration with the Grameen Creative Lab, the Alliance is developing additional projects in Puducherry, India and Tan An, Vietnam that emphasize recycling (AEPW, 2020). The ASASE Foundation project in Accra Ghana trains women to collect and recycle waste (AEPW, 2020). In another collaboration, the Aviral Project seeks to engage the local community in "recovery and recycling" to protect religiously important sites along the Ganga river and to reduce waste from religious festivals (AEPW, 2020:19). AEPW describes the Renew Oceans project in Varanasi, Indian as "the engagement of the area's student population to develop waste management concepts that cover three areas: plastic waste collection, plastic waste conversion and community education" (AEPW, 2020:22). However, as of 2021 the project has been halted, as "the organization has come to the conclusion that it simply does not have the capacity to work at the scale this problem deserves" (Brock et al., 2021: 1).

Collaborating with The Incubation Network in south and southeast Asia has yielded four projects: the Ocean Plastic Prevention Accelerator (OPPA), which focuses on waste management and recycling in Surabaya, Indonesia; the Circular Innovation Jam which asks local communities to "design solutions to advance circular economies" in India, Indonesia, Thailand, the Philippines and Vietnam; the Surabaya Access Pad, which innovates, "plastic pollution prevention products" in Indonesia; and the Plastics Data Challenge which seeks to collect data on "plastic leakage" in south and southeast Asia (AEPW, 2020:23). Of the 21 projects or innovations described in the report, 16 emphasize recycling; one citizen cleanups; one data collection; and for three projects, it is unclear what mechanism they will use to reduce plastic waste (Circular Innovation Jam, Surabaya Access Pad, Kiverdi). Overall, the report mentions reducing plastic leakage, but not reducing plastic production, considering the relative value of different kinds of plastic usage, or the exploration of reasonable alternatives to single use plastics.

It should also be noted that the AEPW, 2020 report mentions "front end design" to "boost recycling rates, support[] materials innovation, and contribute[] to reduction and reuse (AEPW, 2020: 6). In addition, it states the Alliance is "working toward a circular economy, where all people thrive" (AEPW, 2020: 2) and yet most of the projects described in the report focus on endof-pipe solutions. While their report does not provide the full context necessary to deeply evaluate the work of the Alliance, we find it important to note that on the whole, these projects 
and initiatives focus on the symptoms of plastic pollution, not the sources. These kinds of projects may be a part of a longterm comprehensive sustainable plan to reduce global plastic waste and likely provide important opportunities to local NGOs. That said, the AEPW framing ignores the resources that must be used to remake plastics in one form into another, the pollution caused by doing so, and the abysmal rate of global recycling. In summary, the AEPW envisions a future where they continue to produce plastic but address the problem by creating technology that better deals with waste, not its generation. A more comprehensive program to eliminate plastic waste would emphasize front end design rather than pay lip service to circular economy approaches.

\section{COMMON SEAS: PLASTIC DRAWDOWN}

Common Seas is a non-profit based in the UK founded by Jo Royle with some portion of major funding coming from the Lemos family's Avra foundation. In comparison to the Alliance to End Plastic Waste, we analyze the Common Seas' Plastic Drawdown toolkit which more heavily emphasizes the sources rather than the symptoms of plastic waste. Common Seas is "a social enterprise tackling the plastic pollution crisis by driving new policy, investing in the circular economy and catalyzing a cultural shift in how we make, use and dispose of plastic" (Common Seas, 2020a).

The organization promotes a country-level analysis, a sharp decline in single use plastics, and collaborative decision making by stakeholders to "turn off the tap." Their four-phase approach:

- "Models a country's plastic waste mass and composition including future projections to 2030

- Map[s] the waste pathways and leakages,

- Analyzes the impact of key policies, and

- Enable[es] governments to convene key actors and chart a policy pathway toward dramatically reduced ocean plastics" (Common Seas, 2019:3).

Drawdown uses a wedge approach akin to that described by Pacala and Socolow (2004) to combat climate change. Through this approach it seeks to address the sources of plastic waste and leakage. At times, it also uses technological advances, but importantly, moves beyond downstream collection and recycling, instead working collaboratively with communities to develop a pragmatic plan. The 18 potential policy interventions proposed by Common Seas include:

1. Banning some plastics,

2. Taxing to discourage use,

3. Deposit return schemes for beverage containers,

4. Improving access to clean potable water,

5. Water refill schemes,

6. Improving regulation on and handling of plastic pellets,

7. Improved standards and labeling for textiles to reduce microfiber pollution,

8. Better regulation and labeling of tires,

9. Deposit schemes and extended producer reliability concerning fishing gear,
10. Zoning controls in fishing areas

11. Developing waste management collection potentially coupled with a "bring back" scheme that holds producers responsible for the end products they manufacture and sell

12. Better standards for storing and managing waste

13. Creating street-level waste collection to prevent littering

14. Creating systems to deter or penalize littering and unlawful dumping

15. Improving wastewater treatment infrastructure to filter water of plastics

16. Developing sewage and stormwater treatment

17. Tagging fishing gear to prevent illegal abandonment, and

18. Instituting flat rates for port-based waste disposal (Common Seas, 2020b).

Rather than emphasizing downstream options, Common Seas' policy framework includes reduction (2), re-use (1), holding producers accountable (4), addressing underlying problems like clean water access, sewage and water treatment (4), better waste management (4), and measures to reduce waste in the fishing and port industries (3).

Our analysis recognizes that publicly available documents may present an incomplete picture of the work of either of these organizations. It is important to note there are some similarities in the approaches taken by the Alliance to End Plastic Waste and Common Seas. Common Seas also take part in some monitoring and measurement of the plastic problem, while the Alliance to End Plastic Waste also works with local communities and cocreates actions. This is also not meant to condemn the work of the Alliance -which can be a part of a comprehensive effort to reduce plastic pollution - but instead to inform it to better address plastic pollution at the source.

\section{AN ISSUE OF JUSTICE}

Sze and London (2008) define environmental racism as the "unequal distribution of environmental benefits and pollution burdens based on race" while they describe environmental inequality as a broader term that includes, "class, gender, immigration status," and the interactions of these factors as a source of disproportionate environmental impacts (13321333). Scenarios of environmental injustice often include disadvantaged-whether by class, income, status, or racecommunities experiencing higher pollution levels, while not being responsible for high production of said pollution (Pearce et al., 2006). Global environmental justice is not new (Pellow and Brulle, 2005). Pellow and Brulle noted in 2005 that we can expect further environmental injustice from a North-South perspective as, "global North nations continue dumping waste in both domestic and global "pollution havens" where the cost of doing business is much cheaper, regulation is virtually non-existent, and residents do not hold much formal political power" (11).

Bullard (1996) positions environmental injustice as "(1) unequal enforcement of environmental, civil rights, and public health laws, (2) differential exposure of some populations to harmful chemicals... in the home, school, neighborhood, and workplace (3) faulty assumptions in calculating and assessing 
risks, (4) discriminatory zoning and land-use practices, and (5) exclusionary policies and practices that limit some individuals and groups from participation in decision making" (493). The waste burden of plastics on the global south takes on all of these characteristics. In addition, plastic pollution takes on the characteristics of "slow violence" which is the "slow erosion[] of environmental justice" (Nixon, 2011: 8), and the slow onslaught of the social and ecological impacts wrought by plastic waste and plastic pollution. Moreover, the concept of "adaptive injustice" is also applicable to the global plastic environmental justice crisis, where those who have to adapt to increasing plastic waste streams are not the ones responsible for generating the waste (Conlon, 2020).

Experts weigh in on what they believe will be the best approach to the plastic pollution problem. While the Basel Convention (which deals with hazardous and toxic waste), the Stockholm Convention (which deals with Persistent Organic Pollutants or POPs) and the Rotterdam Convention (which focuses on hazardous materials and pesticides) may provide a framework for hazardous waste imports and exports, none were created in response to global plastic pollution reduction (Basel Convention, 2021; Rotterdam Convention, 2021; Stockholm Convention, 2021). The Basel Convention on waste, which added plastic waste amendments in 2019, does not include many common plastics (e.g., polyethylene, polypropelene, and polyethelene terephthalate) if "destined for recycling in an environmentally sound manner" (Basel Convention, 2019). As the implementation of the amendments began in January of 2021, it is still unknown how enforcement might proceed or how effective the Convention may be in reducing the impact of plastic waste. The World Economic Forum (2016) recommend a "systemic approach" ...that moves... "beyond incremental improvements" (3). Haward (2018) calls for an international agreement on par with the Montreal Protocol. Worm et al. (2017) propose “a Global Convention on Plastic Pollution that incentivizes collaboration between governments, producers, scientists, and citizens" (1). Dauvergne (2018) notes that plastics governance, which "reflects industry efforts to resist government regulation, deflect accountability, and thwart critics," fails to "rein in marine plastic pollution" (22). The author recommends "hard hitting domestic regulation" coupled with an international plastics treaty (Dauvergne, 2018: 22). In their 2021 report, the United Nations Environmental Program emphasizes the inherent problem of single use materials, making the distinction that the problem is more about single-use than plastic itself (United Nations Environment Programme, 2021). Their recommendation is for a "systemic transformation of the plastics economy" through a "comprehensive policy response" including designing all products for multiple use, no matter the material, taking local conditions into account, and "addressing the needs" of affected sectors (United Nations Environment Programme, 2021:4). In a collaborative report from the Ellen MacArthur Foundation and United Nations Environment Programme (2020) they strongly prioritize "elimination of problematic or unnecessary plastic packaging through redesign, innovation, and new delivery models" (19).
Watterson and Dinan (2020) in their piece describing the lag of policy behind science in regulating air pollution in England, warn that the dominance of fossil fuel industries in policymaking is detrimental to "ethical and environmental justice decision making with significant consequences for public health (1). The same could be said of plastics regulation. Examples from cigarette manufacturers and petrochemical companies indicate that rather than incorporating scientific data, businesses may take on a strategy to actively thwart accountability (Michaels, 2005; Michaels and Monforton, 2005; Cook et al., 2019).

To combat environmental injustice, Bullard (1994) shares a framework of environmental justice, which includes:

- The right to protection for all people from environmental degradation conceived as a civil right

- Prevention, or "the elimination of the threat before harm occurs" (17).

- Shifting the burden of proof "to the polluters who do harm, discriminate, or do not give equal protection to minorities and other overburdened classes" (39).

- Obviating proof of intent, allowing instead for "disparate impact and statistical weight... to infer discrimination" (40).

- Redressing inequities from the impacts of pollution, through "targeting action and resources... where environmental and health problems are greatest" (41-42).

Overwhelmingly, the AEPW proposals to date emphasize 'better management' through recycling, and frame responsibility around end users in the global south; while the Common Seas approach de-emphasizes recycling and encourages reduction, re-use, and better regulation that holds producers responsible on a global scale. It also addresses some of the problems that make single use plastics a necessity at times, such as lack of access to clean water. The recommendation for an environmentally just response emphasizes that it is the onus of the upstream producers to prevent harm caused by environmental pollutants, not the downstream work of the civic sector and local governments impacted by the pollution.

\section{CONCLUSION}

If you walked into your bathroom to find your tub overflowing with water, would you first begin mopping up the water on the ground, or would you turn off the tap? When manufacturers promote solutions that address the symptoms of plastic pollution but not the source, they leave the tub overflowing while ineffectively mopping up the resulting water. Plastic waste as it is currently understood by industry is an externality that demands a technological solution. Most plastics (over 90\%) originate from virgin fossil fuel stock and most are not recycled (World Economic Forum, 2016). When the problem of plastic waste is ignored, the costs are pushed to marginalized communities around the world, to future generations, citizens, governments, and taxpayers. In some cases, distribution companies take the lead in reducing plastic packaging when manufacturers and governments fail, as can be seen in initiatives taken by the supermarkets Sainsbury, Aldi, Co-Op, and Trader Joe's (Chhabra, 
2019; Goncalves, 2021). For decades, peer-reviewed scientific literature has decried the threats to wildlife; the degradation of ecosystems; the instances of entanglement and ingestion; the accumulation of debris in the gyres and coastal areas; the costs to industries as varied as shipping, tourism, and agriculture; as well as the immense cost to global society to clean up beaches, waterways, and the open ocean. Waste management cannot operate in a vacuum oblivious to the social and environmental harms it causes. Not all plastics are equally useful and many single-use plastics have less environmentally harmful but comparable substitutions available. Some plastics are inexpensive and useful: they can also support important goals in the global south. That said, framing the problem of plastic waste as that of end users, particularly those in developing countries, fails to recognize the complex nature of global plastic markets. Rather than leave the problem-solving to the problem-creators, scientists, policymakers, and governments are advised to frame plastic waste narratives like that of Common Seas: with an emphasis on reduction, redesign, re-use, and

\section{REFERENCES}

AEPW (2019). Alliance to End Plastic Waste Website. Retrieved from: https:// endplasticwaste.org/ (accessed August 12, 2021).

AEPW (2020). Alliance to End Plastic Waste Progress Report 2020. Retrieved from: https://endplasticwaste.org/en/news (accessed 20 May, 2021).

Ammendolia, J., Saturno, J., Brooks, A. L., Jacobs, S., and Jambeck, J. R. (2021). An emerging source of plastic pollution: environmental presence of plastic personal protective equipment (PPE) debris related to COVID-19 in a metropolitan city. Environ. Pollut. 269:116160. doi: 10.1016/j.envpol.2020.116160

Aryan, Y., Yadav, P., and Samadder, S. R. (2019). Life Cycle Assessment of the existing and proposed plastic waste management options in India: a case study. J. Cleaner Product. 211, 1268-1283. doi: 10.1016/j.jclepro.2018.11.236

Azzarello, M. Y., and Van Vleet, E. S. (1987). Marine birds and plastic pollution. Marine Ecol. Prog. Series 37, 295-303. doi: 10.3354/meps037295

Baldwin, A. K., Corsi, S. R., and Mason, S. A. (2016). Plastic debris in 29 Great Lakes tributaries: relations to watershed attributes and hydrology. Environ. Sci. Technol. 50, 10377-10385. doi: 10.1021/acs.est.6b02917

Barnes, D. K., Galgani, F., Thompson, R. C., and Barlaz, M. (2009). Accumulation and fragmentation of plastic debris in global environments. Philos. Trans. $R$. Soc. B Biol. Sci. 364, 1985-1998. doi: 10.1098/rstb.2008.0205

Barnett, F. J. (1997). "Shipping and marine debris in the wider Caribbean: answering a difficult challenge," in Marine Debris (New York, NY: Springer), 219-227. doi: 10.1007/978-1-4613-8486-1_18

Basel Convention (2019). Basel Convention Plastic Waste Amendments. Retrieved from: http://www.basel.int/Implementation/Plasticwaste/ PlasticWasteAmendments/Overview/tabid/8426/Default.aspx (accessed 29 July, 2021).

Basel Convention (2021). Retrieved from: http://www.basel.int/Home/tabid/2202/ Default.aspx (accessed 29 July, 2021).

Blettler, M. C., and Wantzen, K. M. (2019). Threats underestimated in freshwater plastic pollution: mini-review. Water Air Soil Pollut. 230, 1-11. doi: $10.1007 /$ s11270-019-4220-z

Borrelle, S. B., Ringma, J., Law, K. L., Monnahan, C. C., Lebreton, L., McGivern, A., et al. (2020). Predicted growth in plastic waste exceeds efforts to mitigate plastic pollution. Science 369, 1515-1518. doi: $10.1126 /$ science. aba3656

Brock, J., Geddie, J., and Sharma, S. (2021). Big Oil's Flagship Plastic Waste Project Sinks on the Ganges. Reuters. Retrieved from: https://www.reuters.com/article/ us-environment-plastic-insight/big-oils-flagship-plastic-waste-project-sinkson-the-ganges-idUSKBN29N024 (accessed 21 May, 2021). collaborative decision-making for plastic reduction rather than downstream management.

\section{AUTHOR'S NOTE}

Neither of the authors is affiliated with the Alliance to End Plastic Waste or Common Seas in any way.

\section{AUTHOR CONTRIBUTIONS}

$\mathrm{KO}$ and $\mathrm{KC}$ contributed equally to the conceptualization, the writing, and the editing of this manuscript. All authors contributed to the article and approved the submitted version.

\section{ACKNOWLEDGMENTS}

Both authors would like to acknowledge support from the Fulbright Foundation and the National Geographic Society. The authors would like to acknowledge the careful and thoughtful comments provided by two external reviewers.

Bullard, R. D. (1994). Overcoming racism in environmental decision-making. Environ. Sci. Policy Sustain. Dev. 6, 10-44. doi: 10.1080/00139157.1994.9929997

Bullard, R. D. (1996). Environmental justice: It's more than waste facility siting. Soc. Sci. Quart. 77, 493-499. doi: 10.2307/20080668

Cable, R. N., Beletsky, D., Beletsky, R., Wigginton, K., Locke, B. W., and Duhaime, M. B. (2017). Distribution and modeled transport of plastic pollution in the Great Lakes, the world's largest freshwater resource. Front. Environ. Sci. 5:45. doi: $10.3389 /$ fenvs.2017.00045

Carpenter, E. J., and Smith, K. L. (1972). Plastics on the Sargasso Sea surface. Science 175, 1240-1241. doi: 10.1126/science.175.4027.1240

Castro-Jiménez, J., González-Fernández, D., Fornier, M., Schmidt, N., and Sempéré, R. (2019). Macro-litter in surface waters from the Rhone River: Plastic pollution and loading to the NW Mediterranean Sea. Marine Pollut. Bull. 146, 60-66. doi: 10.1016/j.marpolbul.2019.05.067

Charles, D., Kimman, L., and Saran, N. (2021). The Plastic Waste Makers Index. Minderoo Foundation, 1-86. Retrieved from: https://www.minderoo. org/plastic-waste-makers-index/about/ (accessed 12 August 2021).

Chen, C. L. (2015). "Regulation and management of marine litter," in Marine Anthropogenic Litter eds Bergmann, M., Gutow, L., and Klages, M. (Springer, Cham), 395-428. doi: 10.1007/978-3-319-16510-3_15

Chhabra, E. (2019). How Trader Joe's Is Cutting Down on Plastic. Forbes. Retrieved from: https://www.forbes.com/sites/eshachhabra/2019/07/30/howtrader-joes-is-cutting-down-on-plastic/? $\mathrm{sh}=2 \mathrm{fa} 57 \mathrm{f3} 35 \mathrm{fcd}$ (accessed 29 July, 2021).

Clapp, J. (2002). "The distancing of waste: overconsumption in a global economy," Confronting Consumption eds Princen, T., Maniates, M., and Conca, K. (Cambridge, MA: MIT Press), 155-176.

Coe, J. M., and Rogers, D. (Eds.) (1997). Marine Debris: Sources, Impacts, and Solutions. New York, NY: Springer Science \& Business Media.

Common Seas (2019). Plastic Drawdown: Summary. Retrieved from: https:// commonseas.com/programmes/plastic-drawdown (accessed 20 May, 2021).

Common Seas (2020a). Common Seas Website. Retrieved from: https:// commonseas.com/ (accessed 21 May, 2021).

Common Seas (2020b). Plastic Drawdown: A New Approach to Addressing Plastic Pollution From Source to Ocean. Summary for Policy Makers. Retrieved from: https://commonseas.com/programmes/plastic-drawdown (accessed 20 May, 2021).

Conlon, K. (2020). Adaptive injustice: responsibility to act in the plastics economy. Resour. Conserv. Recycl. 153:104563. doi: 10.1016/j.resconrec.2019.104563

Cook, J., Supran, G., Lewandowsky, S., Oreskes, N., and Maibach, E. (2019). America Misled: How the Fossil Fuel Industry Deliberately Misled 
Americans About Climate Change. Fairfax, VA: George Mason University Center for Climate Change Communication. Retrieved from: https://www. climatechangecommunication.org/america-misled/ (accessed 5 May, 2021).

Dauvergne, P. (2018). Why is the global governance of plastic failing the oceans?. Glob. Environ. Change 51, 22-31. doi: 10.1016/j.gloenvcha.2018. 05.002

Dijkgraaf, E., and Vollebergh, H. R. J. (2003). Burn or Bury? A Social Cost Comparison of Final Waste Disposal Methods. Milano: Fondazione Eni Enrico Mattei (FEEM). doi: 10.2139/ssrn.425281

Ellen MacArthur Foundation and United Nations Environment Programme (2020). The Global Commitment 2020 Progress Report. Ellen MacArthur Foundation. Retrieved from: https://www.gpmarinelitter.org/resources (accessed 29 July, 2020).

Eriksen, M., Lebreton, L. C., Carson, H. S., Thiel, M., Moore, C. J., Borerro, J. C., et al. (2014). Plastic pollution in the world's oceans: more than 5 trillion plastic pieces weighing over 250,000 tons afloat at sea. PLOS ONE 9:e111913. doi: 10.1371/journal.pone.0111913

Geyer, R., Jambeck, J. R., and Law, K. L. (2017). Production, use, and fate of all plastics ever made. Sci. Adv. 3:e1700782. doi: 10.1126/sciadv.1700782

Giacovelli, C. (2018). Single-Use Plastics: A Roadmap for Sustainability. UN Environment: Technology for Environment. Retrieved from: https://stg-wedocs. unep.org/handle/20.500.11822/25496 (accessed 5 May, 2021).

Godfrey, L. (2019). Waste plastic, the challenge facing developing countries-ban it, change it, collect it? Recycling 4:3. doi: 10.3390/recycling4010003

Goncalves, M. (2021). Sainsbury's, Aldi and Co-op to Trial Fully Recyclable PlasticFree Sandwich Packaging. The Grocer. Retrieved from: https://www.thegrocer. co.uk/supermarkets/sainsburys-aldi-and-co-op-to-trial-fully-recyclableplastic-free-sandwich-packaging/658352.article (accessed 29 July, 2021).

Gregory, M. R. (2009). Environmental implications of plastic debris in marine settings-entanglement, ingestion, smothering, hangers-on, hitchhiking and alien invasions. Philos. Trans. R. Soc. B Biol. Sci. 364, 2013-2025. doi: $10.1098 /$ rstb.2008.0265

Hardesty, B. D., Lawson, T. J., van der Velde, T., Lansdell, M., and Wilcox, C. (2017). Estimating quantities and sources of marine debris at a continental scale. Front. Ecol. Environ. 15, 18-25. doi: 10.1002/fee.1447

Haward, M. (2018). Plastic pollution of the world's seas and oceans as a contemporary challenge in ocean governance. Nat. Commun. 9:667. doi: 10.1038/s41467-018-03104-3

Heinrich Böll Foundation. (2019). Plastic Atlas: Facts and Figures About the World of Synthetic Polymers. Berlin: Heinrich Böll Foundation, 1-52.

Homer-Dixon, T. F. (2000). Scarcity and conflict. Forum Appl. Res. Public Policy, (Knoxville, TN: University of Tennessee, Energy, Environment and Resources Center) 15:28.

Jambeck, J. R., Geyer, R., Wilcox, C., Siegler, T. R., Perryman, M., Andrady, A., et al. (2015). Plastic waste inputs from land into the ocean. Science 347, 768-771. doi: 10.1126/science.1260352

Kaza, S., Yao, L., Bhada-Tata, P., and Van Woerden, F. (2018). What a Waste 2.0: A Global Snapshot of Solid Waste Management to 2050. Washington, DC: World Bank Publications. doi: 10.1596/978-1-4648-1329-0

Laist, D. W. (1997). "Impacts of marine debris: entanglement of marine life in marine debris including a comprehensive list of species with entanglement and ingestion records," in Marine Debris eds Coe, J. M. and Rogers, D. B. (New York, NY: Springer), 99-139. doi: 10.1007/978-1-4613-8486-1_10

Law, K. L., Starr, N., Siegler, T. R., Jambeck, J. R., Mallos, N. J., and Leonard, G. H. (2020). The United States' contribution of plastic waste to land and ocean. Sci. Adv. 6:eabd0288. doi: 10.1126/sciadv.abd0288

Lebreton, L. C., Van Der Zwet, J., Damsteeg, J. W., Slat, B., Andrady, A., and Reisser, J. (2017). River plastic emissions to the world's oceans. Nat. Commun. 8:15611. doi: 10.1038/ncomms 15611

Lebreton, L. M., Greer, S. D., and Borrero, J. C. (2012). Numerical modelling of floating debris in the world's oceans. Marine Pollut. Bull. 64, 653-661. doi: 10.1016/j.marpolbul.2011.10.027

Lee, R. F., and Sanders, D. P. (2015). The amount and accumulation rate of plastic debris on marshes and beaches on the Georgia coast. Marine Pollut. Bull. 91, 113-119. doi: 10.1016/j.marpolbul.2014.12.019

Liffmann, M., and Boogaerts, L. (1997). "Linkages between land-based sources of pollution and marine debris," in Marine Debris eds Coe, J. M. and Rogers, D. B. (New York, NY: Springer), 359-366. doi: 10.1007/978-1-4613-8486-1_33
McCormick, E., Murray, B., Fonbuena, C., Kijewski, L., Saraçoglu, G., Fullerton, J., et al. (2019). Where Does Your Plastic go? Global Investigation Reveals America's Dirty Secret. The Guardian. Retrieved from: https://www.theguardian.com/ us-news/2019/jun/17/recycled-plastic-america-global-crisis (accessed 20 May, 2021).

Mejjad, N., Cherif, E. K., Rodero, A., Krawczyk, D. A., El Kharraz, J., Moumen, A., et al. (2021). Disposal behavior of used masks during the COVID-19 pandemic in the moroccan community: potential environmental impact. Int. J. Environ. Res. Public Health 18:4382. doi: 10.3390/ijerph18084382

Melillo, W. (2013). How McGruff and the Crying Indian Changed America: A History of Iconic Ad Council Campaigns. Washington, DC: Smithsonian Inst Press.

Michaels, D. (2005). Doubt is their product: industry groups are fighting government regulation by fomenting scientific uncertainty. Sci. Am. 292, 96-101. doi: 10.1038/scientificamerican0605-96

Michaels, D., and Monforton, C. (2005). Manufacturing uncertainty: contested science and the protection of the public's health and environment. Am. J. Public Health 95, S39-S48. doi: 10.2105/AJPH.2004.043059

Miranda, M. L., and Hale, B. (1997). Waste not, want not: the private and social costs of waste-to-energy production. Energy Policy 25, 587-600. doi: 10.1016/S0301-4215(97)00050-5

Moore, C. J., Lattin, G. L., and Zellers, A. F. (2005). "Working our way upstream: a snapshot of land based contributions of plastic and other trash to coastal waters and beaches of Southern California," in Proceedings of the Plastic Debris Rivers to Sea Conference, Algalita Marine Research Foundation (Long Beach, CA).

Mouat, J., Lozano, R. L., and Bateson, H. (2010). Economic Impacts of Marine Litter. Esbjerg: Kommunenes Internasjonale Miljøorganisasjon.

Newman, S., Watkins, E., Farmer, A., Ten Brink, P., and Schweitzer, J. P. (2015). “The economics of marine litter," in Marine Anthropogenic Litter eds Bergmann, M., Gutow, L., and Klages, M. (Cham: Springer), 367-394. doi: 10.1007/978-3-319-16510-3_14

Nixon, R. (2011). Slow Violence and the Environmentalism of the Poor. Cambridge, MA: Harvard University Press. doi: 10.4159/harvard.9780674061194

Owens, K. (2019). Compilation of Publicly Available Data on Founding Members of the Alliance to End Plastic Waste. doi: 10.13140/RG.2.2.17395.48162. Retrieved from: https://bit.ly/3yLhWU8 (accessed August 12, 2021).

Pacala, S., and Socolow, R. (2004). Stabilization wedges: solving the climate problem for the next 50 years with current technologies. Science 305, 968-972. doi: 10.1126/science.1100103

Pearce, J., Kingham, S., and Zawar-Reza, P. (2006). Every breath you take? Environmental justice and air pollution in Christchurch, New Zealand.Environ. Plann. A 38, 919-938. doi: 10.1068/a37446

Pellow, D. N., and Brulle, R. J. (2005). Power, Justice, and the Environment: Toward Critical Environmental Justice Studies. Power, Justice, and the Environment: A Critical Appraisal of the Environmental Justice Movement. Cambridge, MA: The MIT Press. doi: 10.5070/G312410676

PlasticsEurope (2020). Plastics - the Facts 2020. Retrieved from: https:// www.plasticseurope.org/en/resources/publications/4312-plastics-facts- 2020 (accessed May 6, 2021).

Ramirez, R. (2021). 'This is environmental racism': Activists Call on Biden to Stop New Plastics Plants in 'Cancer Alley' The Guardian. Retrieved from: https://www.theguardian.com/us-news/2021/may/17/stjames-parish-formosa-complex-biden-cancer-alley (accessed 21 May, 2021).

Rochman, C. M. (2015). "The complex mixture, fate and toxicity of chemicals associated with plastic debris in the marine environment," in Marine Anthropogenic Litter eds Bergmann, M., Gutow, L., and Klages, M. (Cham: Springer), 117-140. doi: 10.1007/978-3-319-16510-3_5

Rochman, C. M., Browne, M. A., Halpern, B. S., Hentschel, B. T., Hoh, E., Karapanagioti, H. K., et al. (2013). Classify plastic waste as hazardous. Nature 494, 169-171. doi: 10.1038/494169a

Rosevelt, C., Los Huertos, M., Garza, C., and Nevins, H. M. (2013). Marine debris in central California: quantifying type and abundance of beach litter in Monterey Bay, CA. Marine Pollut. Bull. 71, 299-306. doi: 10.1016/j.marpolbul.2013.01.015

Rotterdam Convention (2021). Rotterdam Convention. Retrieved from: http:// www.pic.int/Home/tabid/855/language/en-US/Default.aspx\%20accessed \%2029\%20July, \%202021 (accessed 29 July, 2021). 
Royer, S. J., Ferron, S., Wilson, S. T., and Karl, D. M. (2018). Production of methane and ethylene from plastic in the environment. PLoS ONE 13:e0200574. doi: 10.1371/journal.pone.0200574

Schmidt, C., Krauth, T., and Wagner, S. (2017). Export of plastic debris by rivers into the sea. Environ. Sci. Technol. 51, 12246-12253. doi: 10.1021/acs.est.7b02368

SCP/RAC (2020). Plastic's Toxic Additives and the Circular Economy. Sustainable Consumption and Production Regional Activity Center. Retrieved from: http:// www.cprac.org/en/news-archive/general/toxic-additives-in-plastics-hiddenhazards-linked-to-common-plastic-products (accessed 8 October, 2020).

Silva, A. L. P., Prata, J. C., Walker, T. R., Duarte, A. C., Ouyang, W., Barcel,ò, D., et al. (2020). Increased plastic pollution due to COVID19 pandemic: challenges and recommendations. Chem. Eng. J. 405:126683. doi: $10.1016 /$ j.cej,.2020.126683

Stockholm Convention (2021). Stockholm Convention. Retrieved from: http:// www.pops.int/ (accessed 29 July, 2021).

Sullivan, L., and Gonzales, S. (2020). Waste Land. NPR: Planet Money. Retrieved from: https://www.npr.org/2020/09/11/912150085/waste-land (accessed 12 October, 2020).

Sze, J., and London, J. K. (2008). Environmental justice at the crossroads. Sociol. Compass 2, 1331-1354. doi: 10.1111/j.1751-9020.2008.00131.x

Telesetsky, A. (2019). Why Stop at Plastic Bags and Straws? The Case for a Global Treaty Banning Most Single-Use Plastics. The Conversation. Retrieved from: https://phys.org/news/2019-07-plastic-bags-straws-case-global.html\#: :text= Abandoned\%20plastic\%20goods\%20create\%20breeding,a\%20focus\%20on \%20marine\%20ecosystems (accessed 9 October, 2020).

Teuten, E. L., Saquing, J. M., Knappe, D. R., Barlaz, M. A., Jonsson, S., Björn, A., et al. (2009). Transport and release of chemicals from plastics to the environment and to wildlife. Philos. Trans. R. Soc. B Biol. Sci. 364, 2027-2045. doi: $10.1098 /$ rstb.2008.0284

The Ocean Conservancy (2015). Stemming the Tide: Land-Based Strategies for a Plastic-Free Ocean. Ocean Conservancy and McKinsey Center for Business and Environment. Retrieved from: https://oceanconservancy.org/wp-content/ uploads/2017/04/full-report-stemming-the.pdf (accessed August 12, 2021).

United Nations Environment Programme (2021). Addressing Single-use Plastic Products Pollution Using a Life Cycle Approach. Nairobi: United Nations Environment Programme.
Watterson, A., and Dinan, W. (2020). Lagging and flagging: air pollution, shale gas exploration and the interaction of policy, science, ethics and environmental justice in England. Int. J. Environ. Res. Public Health 17, 4320. doi: 10.3390/ijerph17124320

Williams, R., Ashe, E., and O'Hara, P. D. (2011). Marine mammals and debris in coastal waters of British Columbia, Canada. Marine Pollut. Bull. 62, 1303-1316. doi: 10.1016/j.marpolbul.2011.02.029

World Economic Forum, Ellen MacArthur Foundation, and McKinsey and Company (2016). The New Plastics Economy - Rethinking the Future of Plastics. Retrieved from: https://www.ellenmacarthurfoundation.org/publications/thenew-plastics-economy-rethinking-the-future-of-plastics (accessed 20 May, 2021).

Worm, B., Lotze, H. K., Jubinville, I., Wilcox, C., and Jambeck, J. (2017). Plastic as a persistent marine pollutant. Ann. Rev. Environ. Resour. 42, 1-26. doi: 10.1146/annurev-environ-102016-0 60700

Yang, Y. Y., Rodrigez-Jorquera, I. A., McGuire, M., and Toor, G. S. (2015). Contaminants in the Urban Environment: Microplastics. Gainesville, FL: UF/IFAS Extension.

Conflict of Interest: The authors declare that the research was conducted in the absence of any commercial or financial relationships that could be construed as a potential conflict of interest.

Publisher's Note: All claims expressed in this article are solely those of the authors and do not necessarily represent those of their affiliated organizations, or those of the publisher, the editors and the reviewers. Any product that may be evaluated in this article, or claim that may be made by its manufacturer, is not guaranteed or endorsed by the publisher.

Copyright (C) 2021 Owens and Conlon. This is an open-access article distributed under the terms of the Creative Commons Attribution License (CC BY). The use, distribution or reproduction in other forums is permitted, provided the original author(s) and the copyright owner(s) are credited and that the original publication in this journal is cited, in accordance with accepted academic practice. No use, distribution or reproduction is permitted which does not comply with these terms. 